\title{
象牙質のコンポジットレジンからの未反応物質遮断性
}

九州㮀科大学保存学第 1 講座（指導：長野三代太教授）

河野直博

昭和63年12月 23 日受付

\section{Potentiality of Dentin to Block Residual Substances \\ from Composite Resins}

Naohiro Kawano

Department of Operative Dentistry (Director: Prof. Miyota Nagano)

Kyushu Dental College, Kitakyushu, Japan

Composite resins have been preferably used as the esthetic restorations. However, they sometimes produce certain pulpal irritation. It may be partly attributed to the presence of irritants involving unreacted substances such as residual monomers in the resin restoration. In this study, therefore, the permeability of those substances through dentin structure into pulpal chamber was investigated using sound extracted teeth.

The high speed liquid chromatography revealed that Bis-GMA and Tri-EDMA monomers and a substance having a molecular weight of about 140 were eluted in distilled water from the composite resin used. These residual substances could easily pass through the dentin when the resin was placed in the prepared cavity without removing the smear layer. There could be found no significant increase in the permeability by the acid treatment of the dentinal wall although it has been considered so far that the treatment would result in the increased permeability.

When a light-chemical-curing bonding agent was applied to the acid-etched dentin, the penetration of Tri-EDMA was markedly decreased and that of the unidentified substance was entirely inhibited. A chemical-curing bonding agent, on the other hand, showed no significant effects on the permeability. Furthermore, the $3 \% \mathrm{FeCl}_{3}$ treatment of the dentin prior to applying the bonding agent showed much better ability to block the penetration of these substances, permitting only a small amount of Tri-EDMA to pass.

It was found from SEM observations that the composite resins exhibited fairy tight bonding to the dentinal wall with the aid of the light-chemical-curing bonding agent while the chemical-curing bonding agent produced large interfacial gaps between them. No gaps were observed in the combined use of the light-chemical-curing bonding agent and chemical-curing composite resin on the $3 \% \mathrm{FeCl}_{3}$-pretreated dentin.

Thus the permeability of the residual substances through dentin was well correlated with the presence of the interfacial gaps between the composite resin and dentinal wall. In addition, it was also suggested that the deposits resulting from $3 \% \mathrm{FeCl}_{3}$ treatment 
might play an important role to block the permeation of the residual substances by sealing the dentin tubules.

Key words: Composite resin/Residual substance/Dentin/Permeability

緒言

審美的で菌質の切削量が少なく，また操作性に優れた コンポジットレジンは, 種々の物性の改良によって広範 囲の修復に用いられるようになった。しかしながら，コ ンポジットレジンで修復した後にレジン特有の歯軻症状 が発現するととが多く，てれらの原因を解明するために 数多くの基礎的ならび臨床的研究がなされている1-9!。

コンポジットレジン修復による歯剈道刺激の原因として は，レジン材料そのものの為害作用がまず取り上げら れ, Langeland ら (1966) ${ }^{1}{ }^{\prime}$ ，藤沢ら $(1978)^{21}$ ， Stanley ら $(1979)^{3 \prime}$, Cotton 万 $(1979)^{4}$ は, レジン成分の雪 骫刺激性を指摘している。一方では，レジンの窩洞不適 合による辺縁漏洩や細菌の侵入がその原因として注目さ れ，レシンンの简洞適合性と菌髄刺激との間には少なから ず関係があることが明らかになってきた5ー9!．彼らはレ ジンを曾質と接着させるととによって，霜髄刺激が防止 できる可能性を示唆している.

レジンと歯質を接着させることは，裏装を行わず直接 レシジが象牙質に触れるてとを意味している，さらにレ シンと象牙質との接着を強固にするために，象牙質をも エッチングする方向へと研究が進んできている101。 。 ッチングを行うと種々の刺激が象牙質を通過して歯檤へ 伝わりやすくなることが指摘されている ${ }^{3,4,111}$ 。乙の ような状況下においても，窩洞に充填したレジンの成分 が菊髄を刺激する機序に関しては明らかにされておら ず，ての点に関して早急な解明が必要となってきた。

窩洞に充填されたレジンには，硬化後も刺激性の強い 末反応物質が多く残存しており 12-14)，乙れらが象牙細
管を通過し，歯髄に達するとなんらかの障害を与えるこ とが予想される。しかしながら，象牙質が未反応物質の 通過を遮断することも考えられ，ての点は明らかではな い.そてで，ヒトの新鮮抜去歯牙と市販のコンポジット レジンを用い，象牙質を通過してくるコンポジットレジ ンの未反応物質を分析し，レジンの成分による荬娟刺激 発現の可能性について検討した。

\section{実 酫 材 料}

実験に使用した茵牙は, 蒸留水中に保存した抜去後 3 日以内の健全なとト抜去大臼歯である.コンポジットレ ジンは Table 1 に示したように Clearfil F II（以下 F I と略), Photo Clearfil A (以下 PA と略) の 2 種類 で, エッチング剤, ボンディング材はそれぞれ付属のも のを使用した。なお PAはユニバーサルペーストのみを 使用した。また象牙質専用の処理剤として $3 \% \mathrm{FeCl}_{3}$ 溶液を用いた。さらにボンディング材からの成分の象牙 質通過をみるために，コンポシッッレジンの代りにアマ ルガム（松風社製 Spherical-D）を用いた実験も行っ た。

\section{実 験 方 法}

\section{I ． 未反応物質の分析}

各コンポジットレジン $0.1 \mathrm{~g}$ を内径 $2.5 \mathrm{~mm}$ のテフロン 製モールドの中に填塞し，重合硬化させた．ＦＩはュニ バーサルペーストとキャタリストペースト各 $0.05 \mathrm{~g}$ を採 取, 練和し, 一括で填塞した。PA は2 回積層法を用 い, 各填塞ごとに30秒間光照射した。 照射器には Day Light（松風社製）を使用した。硬化後ただちに各コン

Table 1 Materials used

\begin{tabular}{llll}
\hline \hline Code & Material & Curing type & Manufacturer \\
\hline F II & Clearfil F I & Chemical & Kuraray \\
P A & Photo Clearfil A & Light & Kuraray \\
\hline N B & Clearfil New Bond & Chemical & Kuraray \\
P B & Clearfil Photo Bond & Light \& Chemical & Kuraray \\
\hline
\end{tabular}

Etching agent : Clearfil etching agent

Pretreating agent : $3 \% \mathrm{FeCl}_{3}$ solution 
ポジットレジンを $5 \mathrm{ml}$ の蒸留水中に浸漬し， $37^{\circ} \mathrm{C}$ 湿度 $100 \%$ の暗所に保存した． 2 週間後，蒸留水中に含まれ ているレジンから溶出してきた未反応物質を慶田(1982) 13) の方法で抽出し，高速液体クロマトグラフ LC-3 A (以下液ク口之略) で分析した．カラムはWB-G-20 (和 光社製) 2 本を直列に連結して使用した. 移動相にはテ トラヒドロフラン（以下 THF と略）を用い，分析条 件は Absorbance : $0.08 \mathrm{mV}$, Pressure limit : 100kg $/ \mathrm{cm}^{2}$, Flow rate : $1 \mathrm{ml} / \mathrm{min}$, UV wave length : $254 \mathrm{~nm}$, Chart speed : $5 \mathrm{~mm} / \mathrm{min}$ とした.

\section{I . 未反応物質遮断性}

実験に用いた試験片の模式図を Fig. 1 に示す.ヒト の抜去大曰菌を，解剖学的歯頸線付近で切断して，歯㖪 側から天蓋部分をダイヤモンドポイントにて平坦にし た。形成面をエッチング剤で60秒間処理し，歯鹃側の象 牙細管を開放状態にした，その後，咬合面から残存象牙 質が $2.0 \mathrm{~mm}$ となるように，直径 $2.5 \mathrm{~mm}$ の窩洞を形成 した.ての䈑洞に以下の 5 通りの方法で修復を行った。

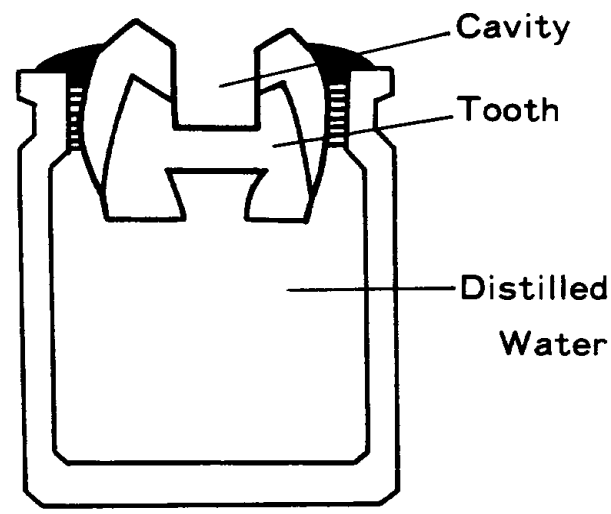

Fig. 1 Schematic representation of permeability test.

1) 窩洞をエッチングせず，ボンディング材なしに直接 コンポジットレジンを充填

2 ）窩洞を60秒間リン酸エッチング，水洗，乾燥した後 ボンディング材なしに直接コンポジットレシンをを充媜

3）窩洞を60秒間りン酸エッチング, 水洗, 乾燥し,ボ ンディング材を塗布した後，コンポジットレジンを充 填

4）窩洞を60秒間リン酸エッチング, 水洗, 乾燥し,さ らに $3 \% \mathrm{FeCl}_{3}$ 溶液で60秒間処理, 水洗, 乾燥し, ボ ンディング材を塗布した.コンポジットレジン $(\mathbf{F} \mathbf{I})$ を充填

5 ）窩洞を60秒間リン酸エッチング，水洗，乾燥し，ボ
ンディング材を塗布した後，アマルガムを充填

化学重合型ボンディング材クリアフィルニューボンド (以下 NB と略) は，塗布後軽くエアーをかけるだけ上 した. 光化学重合型ボンディング材クリアフィルフォト ボンド (以下 PB と略) の場合は，エアーをかけた後， 10秒間光照射した. コンポジットレジンの量は $0.1 \mathrm{~g}$ し, 化学重合型の F I は練和後一括で填塞を終了した。 光重合型の PA は 2 回積畣法により, 各 30 秒間光照射 在行って, 重合硬化させた.アマルガムの混永比はメー カ一指示とし，アマルガムミキサー “DELUXE”（松風 社製）を用いて15秒間練和を行い，窩洞に填塞した。そ れぞれの試験片は, 蒸留水 $5 \mathrm{ml} て ゙$ 満たされた試料ビン 中に菌鹃腔側が蒸留水に接するように取り付け (Fig. $1 ， 37^{\circ} \mathrm{C}$ 湿度 $100 \%$ の暗所に 保存した. 2 週間後, 蒸留水中の未反応物質を前述の方法で分析し，修復物か ら象牙質を通過して画髄腔側に達した物質およびその量 を求めた。

III. 象牙質処理面およびレジンと䆟底との接合状態の

\section{SEM 観察}

修復する前の窩底象牙質，すなわち墭洞形成後，60秒 間リン酸エッチング後, ならびに $3 \% \mathrm{FeCl}_{3}$ 処理後の 各窝底の表面と雪牙の煩舌的方向の割断面の状態を，走 查型電子顕微鏡（日本電子社製 JSM-T 300）に上り観 察した。

末反応物質遮断性の実験後の試験片を低速精密切断機 アイソメット (Buehler 社製) で煩舌的方向に切断し, コンポジットレジンと窩底との接合状態について SEM 観察を行った。なお SEM 観察用試験片作製時の乾燥お よび減圧の影響を考虑して，レプリカ法も併用した．

\section{結果}

\section{I . 未反応物質の分析}

コンポジットレジンの各ペーストを直接 THF に溶解 させたもののクロマトグラムを Fig. 2 に示す. Fig. 2 の上は FIIユニバーサルペースト，中は FIIのキャ タリストペースト，下はPAのュニバーサルペースト についてである。

F I と PA の硬化物を蒸留水中に浸漬し, 溶出して きた末反応物質のクロマトグラムを Fig. 3 亿示す.ま た, Bis-GMA, Tri-EDMA, Di-EDMA, EDMA お よび THF の標準試料を用い，逆相分配クロマトグラ フィ一 (以下 GPC と略) における分子量と保持時間と の関係を Fig. 4 亿示す. Fig. 4 をもとに Fig. 3 で得 られたピークを同定すると，硬化した F I の中に含ま 

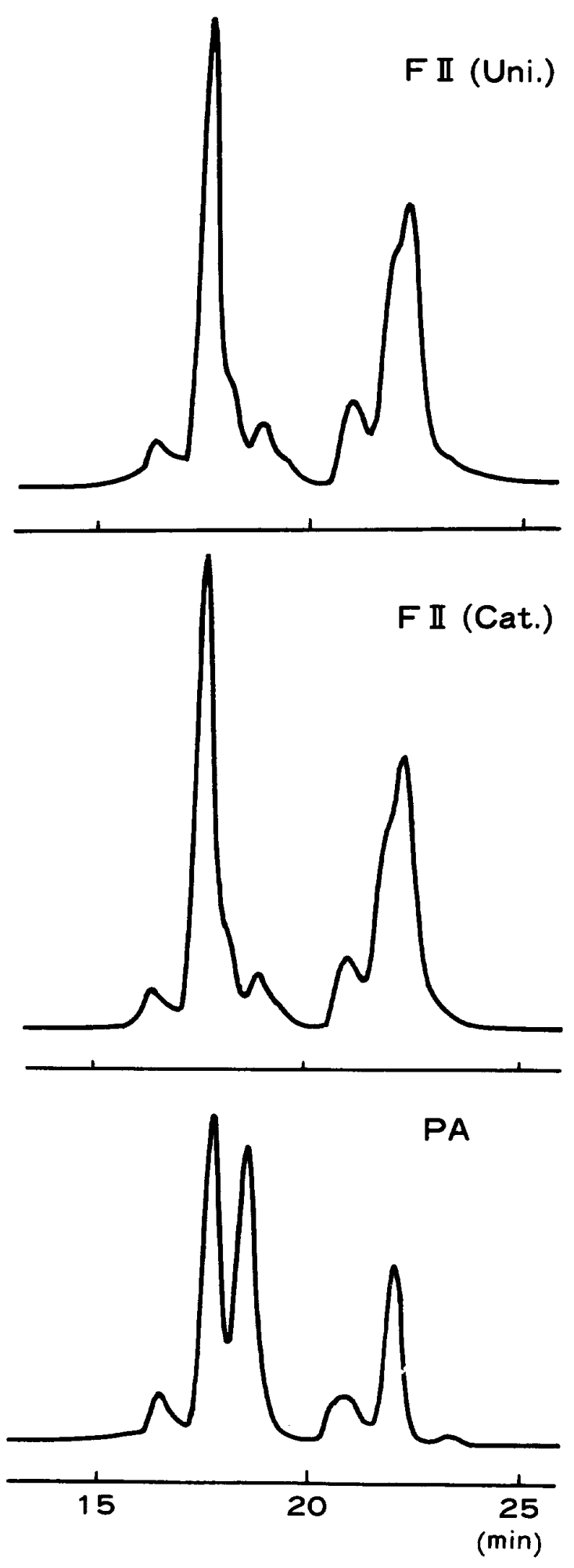

Retention time

Fig. 2 Chromatogram for components of composite resins.

れる主な末反応物質は Bis-GMA，Tri-EDMA とそ の他 1 種類の未反応物質であった，同様に，硬化した

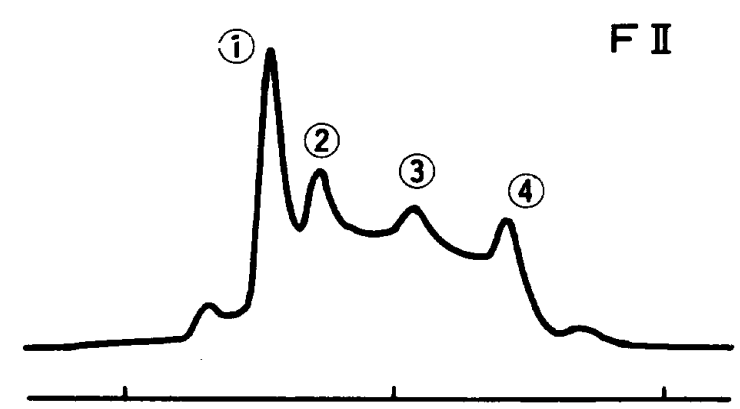

PA

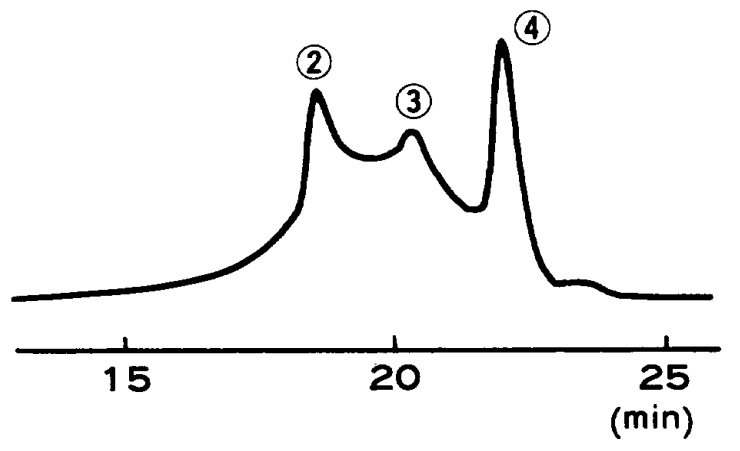

Retention time

Fig. 3 Chromatogram for residual substances of composite resins.

(1) Bis-GMA (2) Tri-EDMA (3) Un. identified substance (4) THF

PA からは Tri-EDMA と F II の場合と同じ未知物質 1 種類が検出された。F II, PA の未知物質は, 分子量 が 140 付近のものであった.なお，組成分析には液ク口 の分析条件をカラム：シリカの ODS-C-5, 移動相：メ タノール 80\%, UV wave length : $214 \mathrm{~nm}$ として行 ったクロマトグラムと赤外分光分析の結果も参考とし た.

II . 未反応物質遮断性

Bis-GMA，Tri-EDMA および分子量が140付近の未 反応物質について，修復物から象牙質を通過して蒾髄腔 側に達した量を定量分析した，Bis-GMA，Tri-EDMA はそれぞれのクロマトグラムのピークの高さと THF に 溶解しているモノマーの量が比例するととを確認し，そ の検量線に従って，通過量の定量を行った，未知物質に ついては同量の硬化物を蒸留水中に浸漬させ，同期間で 蒸留水中に拡散してきた場合と比較し，ピーク面積の百 分率で求めた。なお，統計的な有意差の判定には各末反 忘物質でとに，試験片の種類による一元配置分散分析を 行い，水準間の検定には $\mathrm{t}$ 検定を用いた.

象牙質をリン酸でエッチングした場合の影響を Fig. 


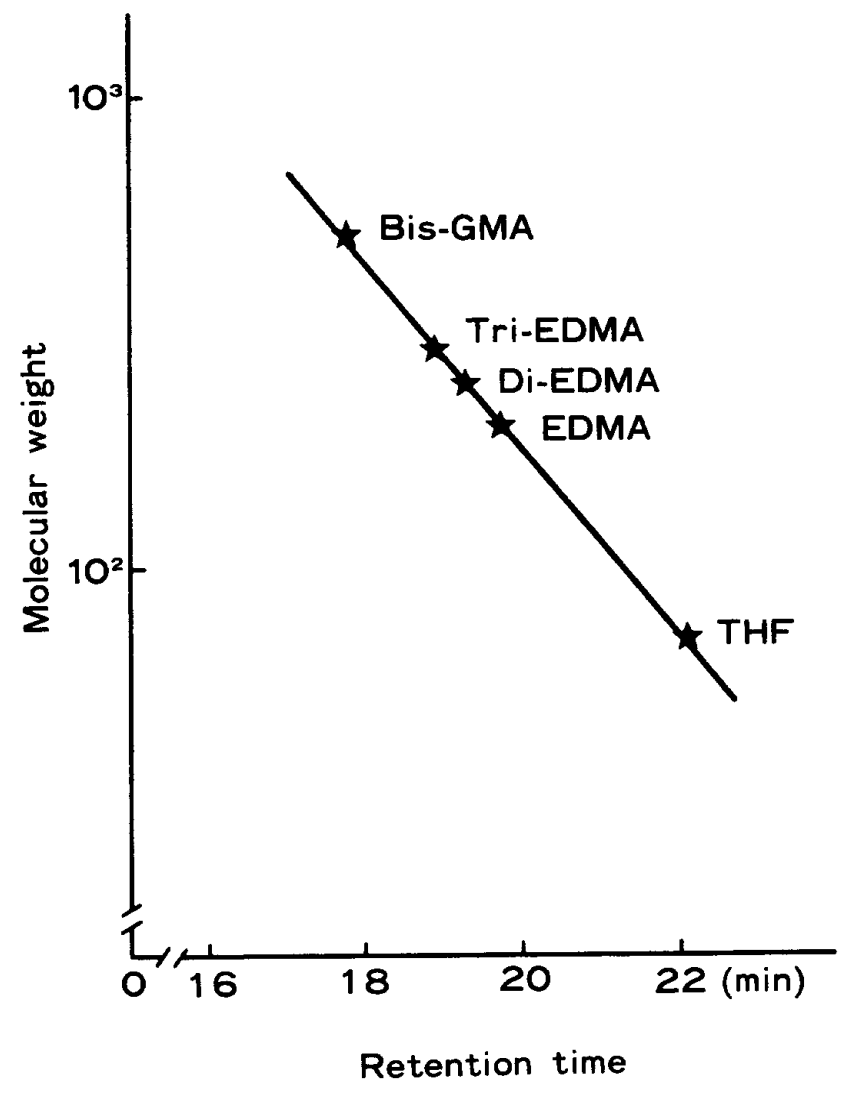

Fig. 4 Relation of molecular weight with retention time.
5 亿示す. Bis-GMA と Tri-EDMA は重量で, 未知 物質は百分率で示している。コントロールは，硬化物を 直接蒸留水中に浸漬した時に溶出してきた未反応物質で ある．象牙質を通過してきた物質の中で，Tri-EDMA の通過量はコントロールのほぼ半分程度であった $(\mathbf{P}<$ 0.01). Bis-GMA と未知物質は, コントロールと大き な差はなかった，象牙質をエッチングしても，末反応物 質の通過量に差は生じなかった。

ボンディング材の影響を Fig. 6 亿示す.ボンディン グ材 NB を使用すると，PA 中の Tri-EDMA の通過 が減少した $(\mathbf{P}<0.01)$. F I 亿関しては有意な差はな かった。ボンディング材 PB を使用した場合， FII， PA ともに Tri-EDMA の通過が減少し $(\mathrm{P}<0.05)$, 未知物質の通過が全く認められなくなった。また F I 中の Bis-GMA の通過量には，ボンディング材を使用 した場合としない場合との間で有意な差はみられなかっ た。

象牙質処理剤 $\mathrm{FeCl}_{3}$ の影響を Fig. 7 亿示す. 今回, 条件を統一するために $\mathrm{FeCl}_{3}$ 処理は，リン酸エッチン グした後に行った。コンポジットレジンは，F【のみで ある. $\mathrm{FeCl}_{3}$ 処理すると Bis-GMA の通過が喼められ なくなった。

Tri-EDMA と未知物質の通過量は，処理しなかった

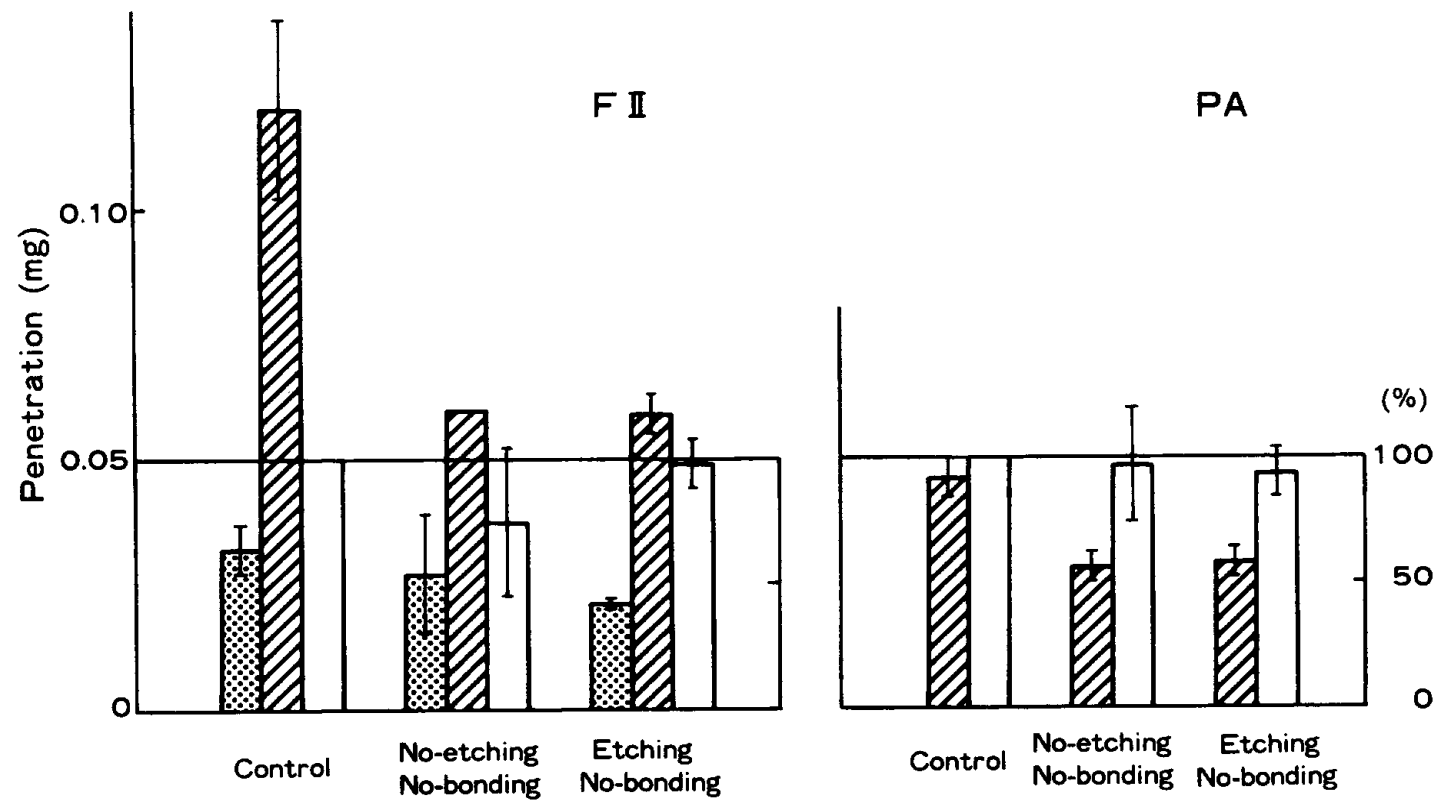

Fig. 5 Effects of etching of dentin on the penetration of residual substances through dentin from composite resin.

Bis-GMA $\square$ Tri-EDMA $\square$ Unidentified substance 

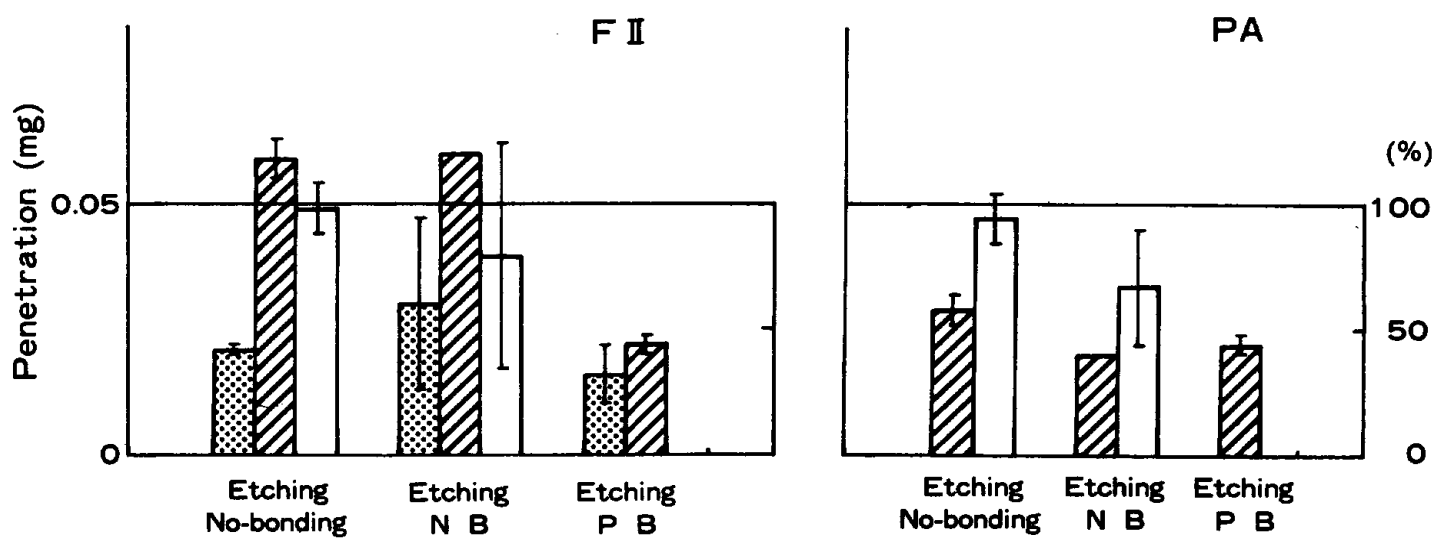

Fig. 6 Effects of bonding agent on the penetration of residual substances through dentin from composite resin.

$\because$ Bis-GMA Tri-EDMA $\square$ Unidentified substance

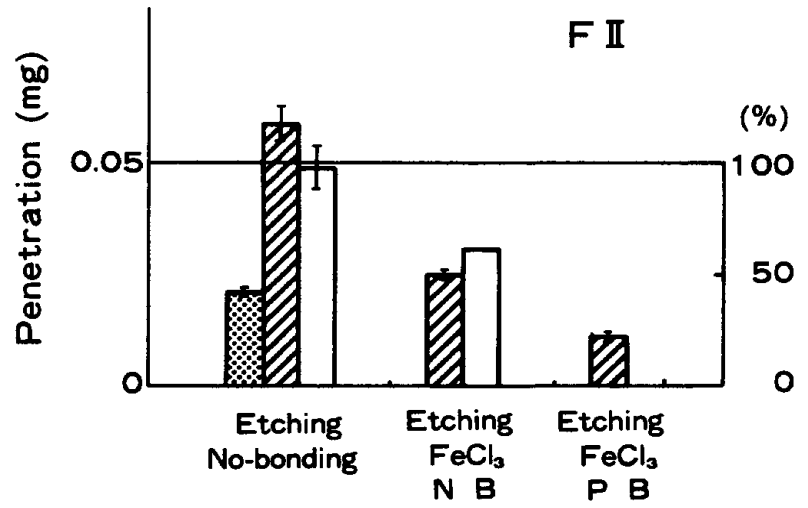

Fig. 7 Effects of $3 \% \mathrm{FeCl}_{3}$ treatment on the penetration of residual substances through dentin from composite resin.

$\because$ Bis-GMA Tri-EDMA

Unidentified substance

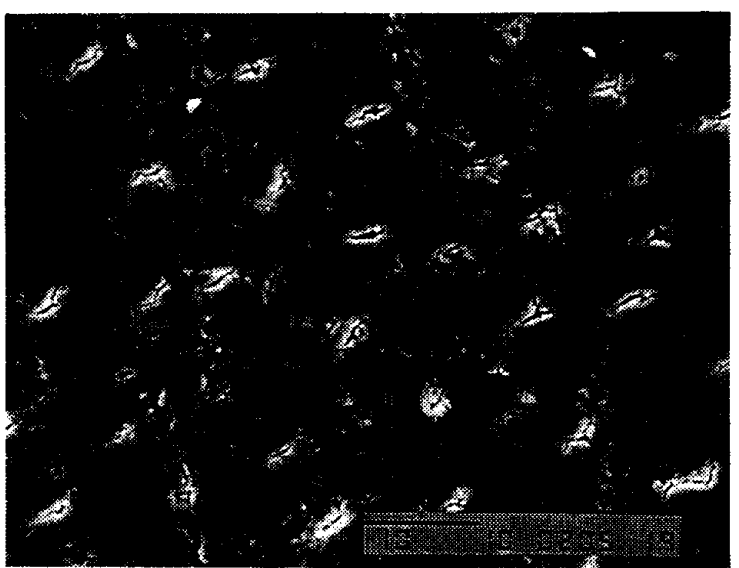

場合より減少した $(\mathbf{P}<0.01)$ 。さらにボンディング材 PB を使用した場合，象牙質を通過してきた未反応物質 は，Tri-EDMA のみであった。

なお，ボンディング材を塗布し，その上にアマルガム を充填した場合, 象牙質を通過するボンディング材の未 反応物質は全く認められなかった。

H. 象牙質処理面およびレジンと窩底との接合状態の SEM 観察

㸗洞形成後の窩底象牙質ならびにその割断面を Fig. 8 に示す. 表渞はスミア一層でおおわれ，象牙細管はス ミアー層で大部分閉鎖された状態であっだ、細管内にも 切削片と思われる微細な粒状物が認められた．

リン酸で60秒間エッチングした窩底象牙質ならびにそ の割断面を Fig. 9 亿示す. スミア一層は，完全に除去 され，細管がロート状に拡大した像として見られた。

リン酸でエッチングした後， $3 \% \mathrm{FeCl}_{3}$ 溶液で60秒間

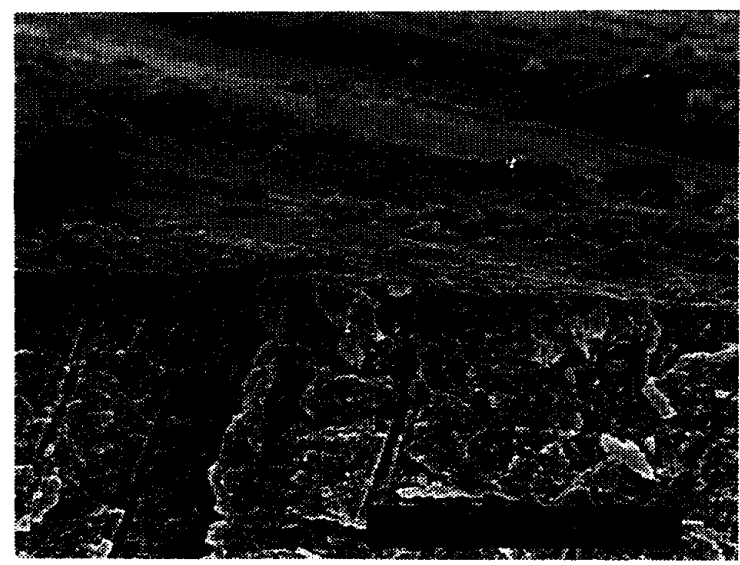

Fig. 8 Surface and cross section of dentin after cavity preparation. (SEM, $\times 2,000)$ 

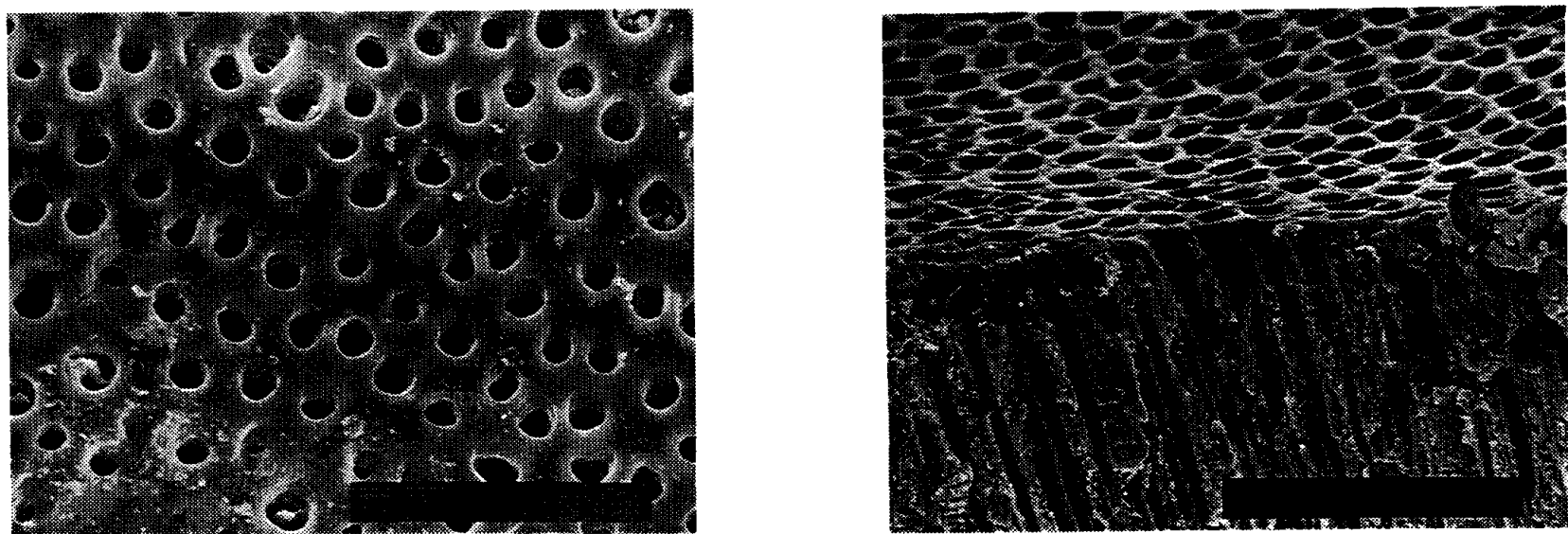

Fig. 9 Surface and cross section of dentin after treated with phosphoric acid. (SEM, $\times 2,000$ )
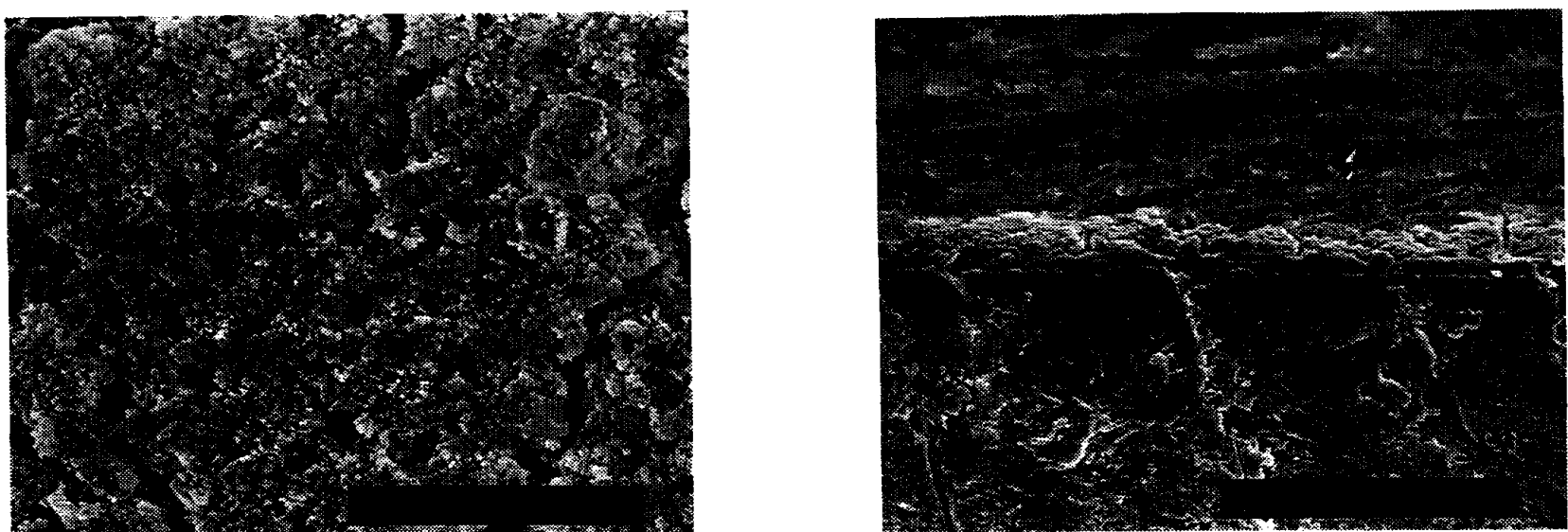

Fig.10 Surface and cross section of dentin after treated with $3 \% \mathrm{FeCl}_{3}$ solution. (SEM, $\times 2,000$ )

処理した窩底象牙質ならびにその割断面を Fig.10に示 す.表風には新しい析出物が形成されており，乙れは細 管内にも存在していた。

レシシンと䆚底象牙質との接合状態を Fig.11〜13 に示 す. NB と FI (Fig.11左), NBと PA (Fig.12左)

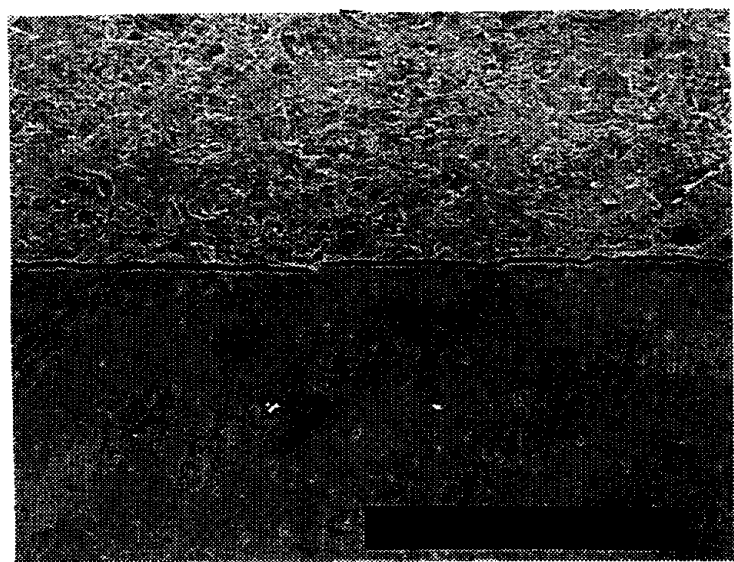

の組み合せでは，幅広いギャップが認められた．PB と PA（Fig. 12右）の組み合せでは，部分的にギャップ が存在していた。PB と FII（Fig. 11右）および $3 \%$ $\mathrm{FeCl}_{3}$ 処理をした場合 (Fig. 13)，ギャップは諗められ なかった。

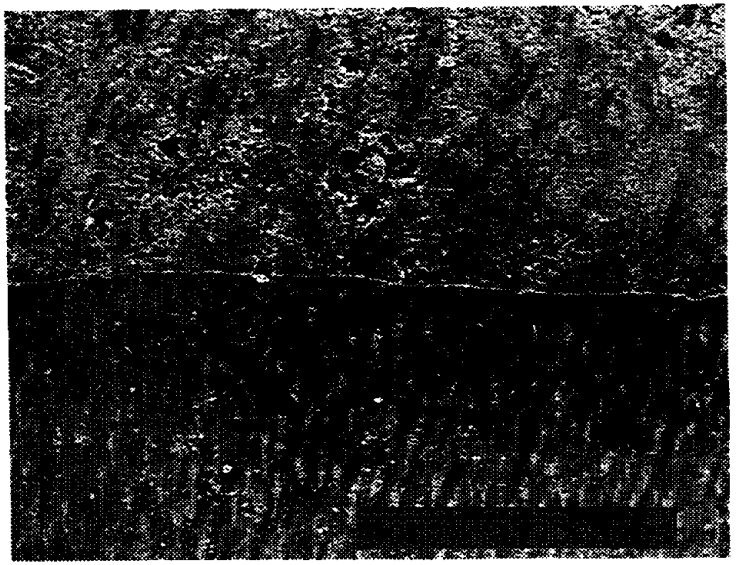

Fig.11 Cross-sectional view of the interface between composite resin and acid-etched dentin. left : NB and FI right : PB and F I

$(\mathrm{SEM}, \times 350)$ 

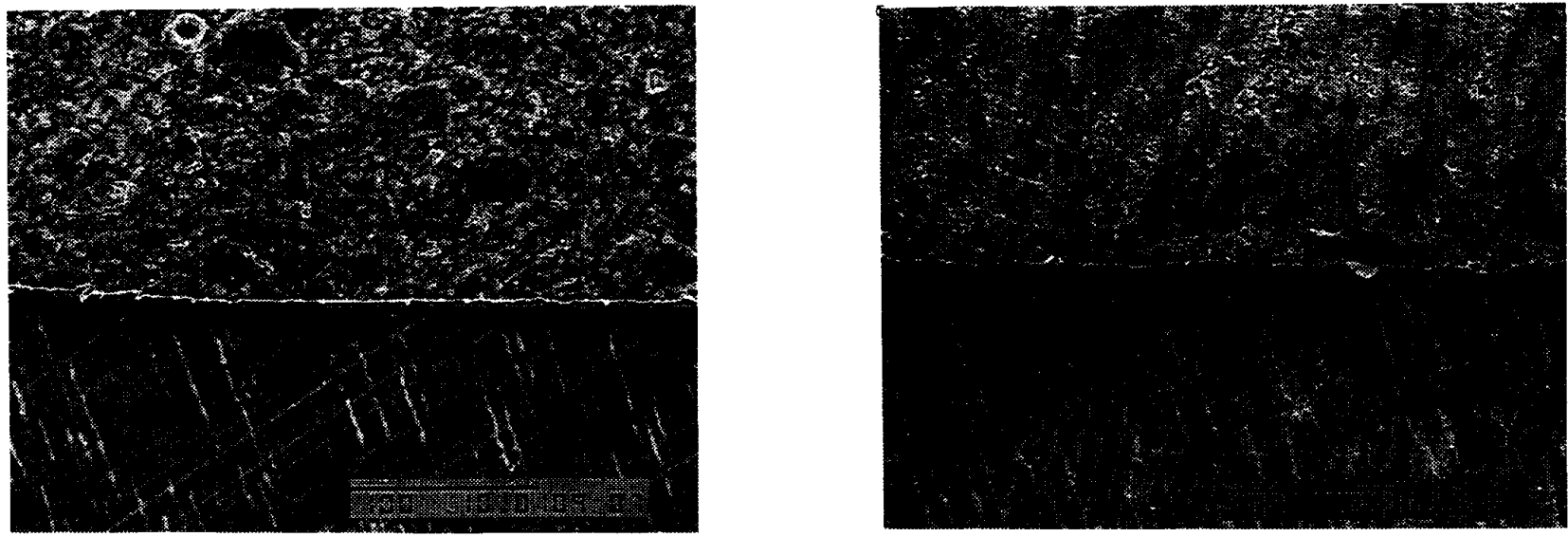

Fig.12 Cross-sectional view of the interface between composite resin and acid-etched dentin. left: NB and PA right: $P B$ and PA

$($ SEM, $\times 350)$
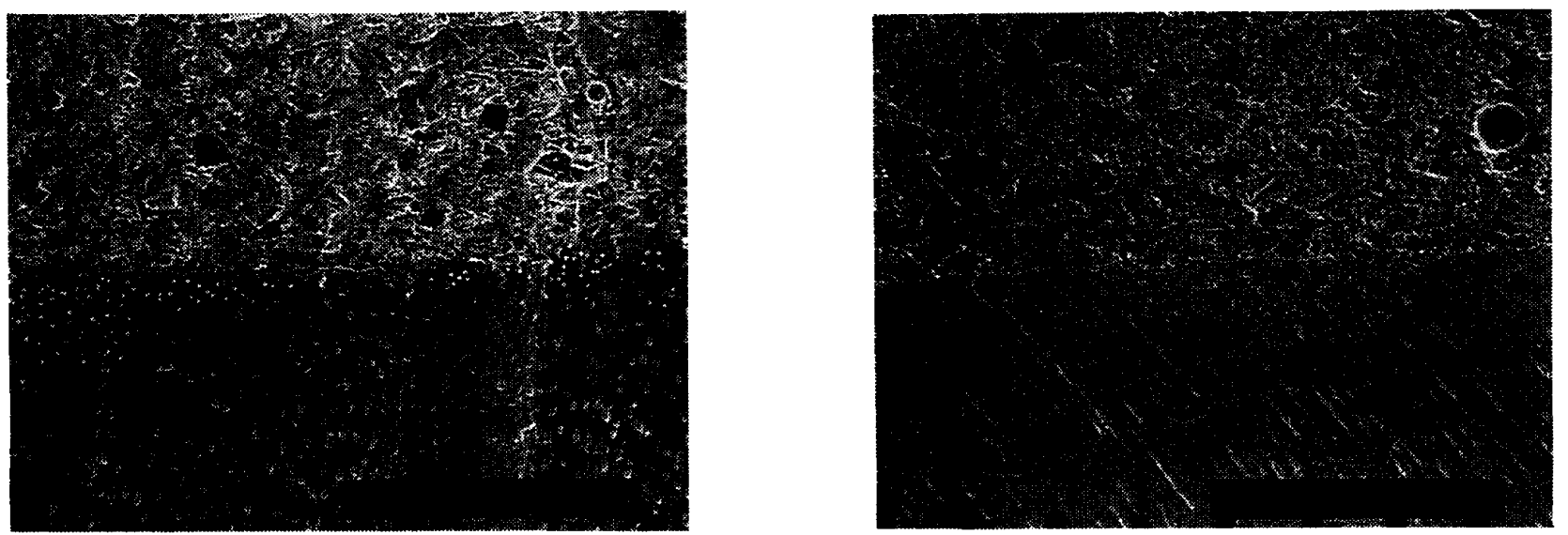

Fig.13 Cross-sectional view of the interface between acid-and $3 \% \mathrm{FeCl}_{3}$ - treated dentin. left : NB and F II right : PB and F I

$($ SEM, $\times 350)$

\section{考寀}

コンポジットレジン修復を施した後，レジン特有の崡 髄症状を起こすととがあり，臨床上大きな問題となって いる．乙の原因については種々の考えが出されているが $1,6,7,9)$ ，明確に特定されるまでにはいたっていない.

コンポシットレシン材料は, 生体に対して為害作用を 持つことが種々の研究で明らかである 15-17)。成分中の 刺激物としてはベースレジン，希釈材，触媒などがあ り，レジン硬化後もこれらの一部が未反応のまま残留し ている、刺激物である未反応物質が象牙質を通過し，歯 髄を刺激することは十分考えられ，この点について明ら かにすることがこの研究の目的である.

化学重合型コンポジットレジン F II を蒸留水に浸漬 すると，主成分である Bis-GMA，Tri-EDMA の残留 モノマーと分子量 140 付近の物質の溶出が認められた. 一方, 光重合型コンポジットレジン PA の場合は, 溶
出した末反応物質は Tri-EDMA と分子量140付近の物 質のみであり，Bis-GMA の溶出は認められなかった。 PA の重合前のペーストには Bis-GMA は含まれてい る (Fig. 2) が, その量は少なかった.したがって, 重 合後蒸留水に溶出するほど多量にはモノマーは残留しな いものと思われる. 分子量 140 付近の物賈は同定できな かったが，分子量から考えて，モノマーとは考えにく い. 重合禁止剤やモノマーが解離したものなどが考えら れる.しかしこの物質が歯髄に達しても剌激物とならな いという保証はない。

形成した窝洞にコンポジットレジンを前処理なしに直 接填塞した場合，いすれれの未反応物質も象牙質を通過 し，雨髄腔側に達することが確認された。

窩洞形成を行うと窩底象牙質表面には，スミア一層が 形成される.Fig.8 にみられるように，窩底表層にあ る象牙細管はこの層におおわれて開口部は非常に細かく なっている，それにもかかわらず，未反応物質の通過量 
はかなり多く，Bis-GMA および未知物質についてはレ シン試験片を水中に浸漬した場合の溶出量とほぼ同程度 であった. Tri-EDMA のみ, 通過量は水中に浸漬した 場合の溶出量の半分程度にすぎなかったが, 長期的にも 少ないかどうかは疑問である。一方，スミアー凰はレジ ンと象牙質との接着を阻害する因子と言われ，レシン修 復を行う前に前処理剂を使用して除去するてとが勧めら れている10,18-20). 前処理をすることによって，スミ ア一層は除去され，種々の刺激が象牙質を通過して柬髄 へ伝わりやすくなると言われている ${ }^{3,4,11)}$.リン酸で エッチングした象牙質は，スミア一層が除去されている ばかりでなく，象牙細管の開口部も拡大する(Fig.9). 当然，レジンの成分がより通過しやすくなることが予想 されたが， 2 種類のコンポジットレシンの未反応物質の 象牙質を通過する量には，リン酸処理の有無による差は 認められなかった (Fig.5)。乙れらの結果から，象牙 細管が完全に封鎖されていない限り，未反応物質は容易 に通過し得ることがわかった．このように象牙細管がス ミアー層におおおれていても未反応物質は容易に象牙質 を通過したことは注目すべきととであり，スミア一層に モノマーのような未反応物質を遮断する効果を期待する ことはできない.

ボンディング材として化学重合型 NBと光化学重合型 PB の 2 種類を用いて，レジン修復物からの未反忘物質 遮断性を検討したところ, PB の方がやや有効であっ た.ボンディング材を塗布し，その上にアマルガムを充 填した試験片においては, 象牙質を通過した物質は全く 認められず，ボンディング材自体からの成分の通過はな いととが確認された，NBと PB の主成分は同じであ り, 両者でレジン修復物からの象牙質通過量に差が生じ た原因としては，Fig.11，12にみられるようなレジン

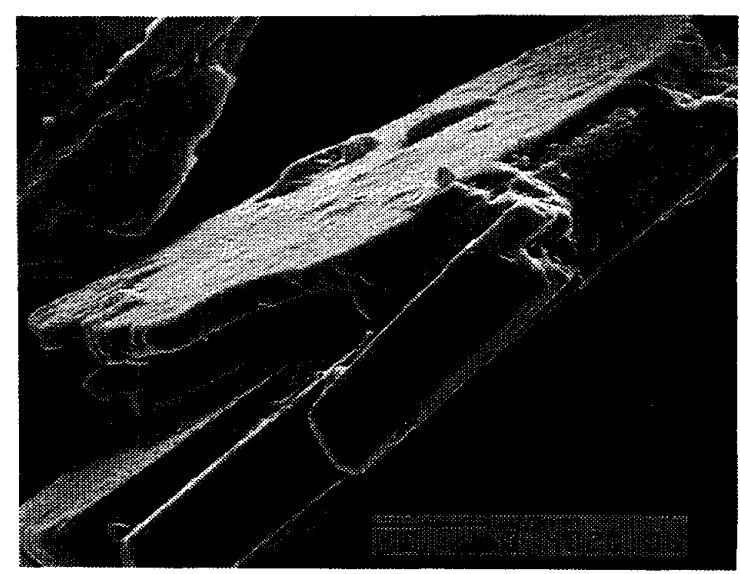

と窩壁との間に生じたギャップの大きさの違いが考えら れる．PB の場合，レジンを填塞する前にすでに光照射 により重合して蒾質と接着しているため，レシンン重合 収縮に伴う窩底との間のギャップが生じにくくなるもの と思われる。したがって，レジン修復物が歯艏腔側から 浸透してきた水と触れる機会が NB の場合より少なく， そのため未反応物質の象牙質通過量が少なくなったと考 えられる.また，NB は塗布後, エアーをかけるだけで あり，成分中のエタノールが十分飛散せず，てれが溶剤 となって未反応物質の溶出を増大させた可能性も無視で きない。

冨士谷 $(1986)^{91}$ は二ホンザルの蒾を用いレジン修復 における歯髄刺激を組織学的に検索した結果，レジンと 象牙質窩壁間に生じたギャップの存在が粜髄刺激を意起 させる可能性があると述べている．その機序について は, 温度的，機械的刺激によるギャップの容積変化が象 牙細管内組織液に何らかの影響を及ぼし，歯䯋に刺激が 加わるのではないかと推測している。しかし，本実験か らギャップが存在するとレジンの未反応物質が歯髄へ達 する可能性が高くなると考えられ，単なる物理的刺激だ けではなく，未反応物質が雬䯙を刺激した疑いも大きい のではないかと思われる。

象牙質を $\mathrm{FeCl}_{3}$ で処理した場合, 未反応物質の通過 量が減少し，Bis-GMA は全く通過しなかった. 象牙質 の成分である $\mathrm{HAp}$ ⿸ $\mathrm{FeCl}_{3}$ で処理すると， HAp の 表面に微細な析出物が付着する (Fig.14)。畫ら（1987） 21)は HAp とボンディング材との化学的接着は認めら れるが，水中浸漬によって両者間にギャップが生じ，ボ ンディング材と HAp の接着は不十分であると述べてい る.同様な方法で $3 \% \mathrm{FeCl}_{3}$ 処理した $\mathrm{HAp}$ とボンディ ング材を反応させ， 2 週間水中に浸漬させたところ，ギ

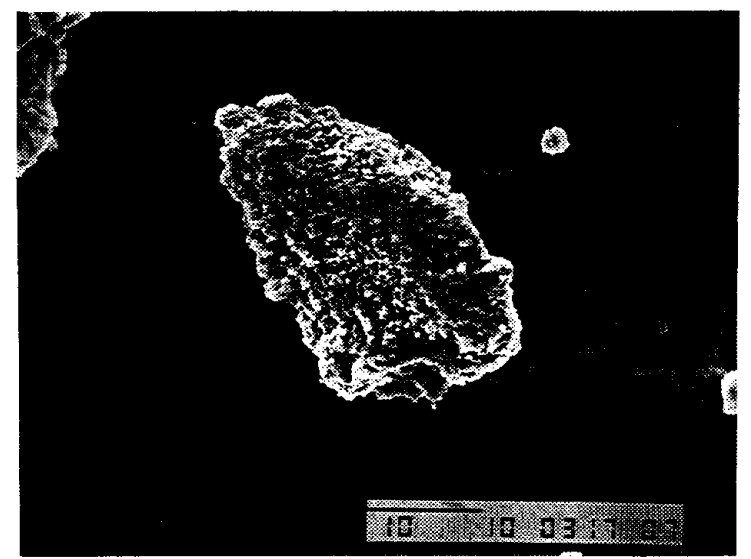

Fig.14 Synthetic hydroxyapatite.

left: untreated right: after treated with $3 \% \mathrm{FeCl}_{3}$ solution

$(\mathrm{SEM}, \times 2,000)$ 

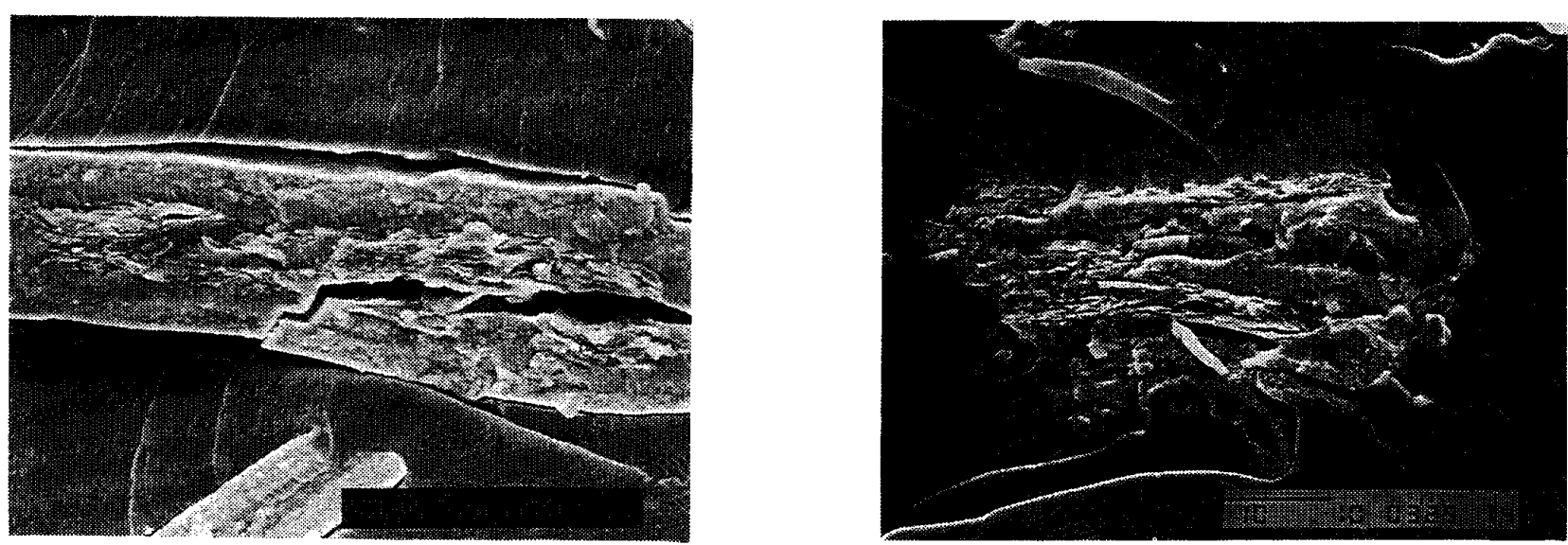

Fig.15 Fracture surface of NB-HAp specimen after it was fractured and stored in water for 2 weeks.

left : untreated HAp used

right : $3 \% \mathrm{FeCl}_{3}$ solution treated $\mathrm{HAp}$ used $(\mathrm{SEM}, \times 2,000)$

ヤップは生じなかった(Fig.15).てのような接着力の改 善が微細な析出物による機械的なものなのか化学的なも のなのかは不明である。また，中林ら(1987) ${ }^{22}$ は $\mathrm{FeCl}_{3}$ がコラーゲンに作用し，レジンと象牙質との接着を高め ると述べている．いずれにせよ象牙質を $\mathrm{FeCl}_{3}$ で前処 理することにより，レジンと窩壁とのギャップはほぼ消 失し，末反応物質の通過が少なくなったものと考えられ る.また，微細な析出物は象牙細管内にも存在しており， 細管の物理的な封鎖性を増加させたとも考えられる。さ らに，通過してきた未反応物質の中でやや親水性のある Bis-GMA は，乙の析出物に吸着し，茵髄側入通過しな かった可能性もあると推察している. 門磨ら (1988)23) は第 2 鉄イオンが MMA の重合の助触媒となりうるこ とを示唆している，通過してきたコンポジットレシンの 末反応モノマーに第 2 鉄イオンが関与し何らかの変化が 起ったとも考えられるが，ての点は明らかではない，

F II ， PA 付属のボンディング材 NB， PB を，コン ポジットレジンと併用せずに象牙質に応用した場合，そ の成分が象牙質を通過するととは全く認められなかっ た・とれは象牙質知覚過敏症の治療にボンディング材単 独使用で，かなりの効果をあげていること 24)の裏付け となる結果であると考えられる.すなわち，ボンディン グ材は歯哊を刺激せずに象牙細管を封鎖し，外来刺激を 遮断することによって知覚過敏が減弱あるいは消退した のであろうと推察される.

今回実験に用いたヒト健全抜去歯の象牙質は，コンポ ジットレジンの未反応物質を完全には遮断しなかった． 臨床でのレジン修復の適応はう蝕㐘がほとんどである． 黒崎ら (1987 $)^{251}$ が指摘しているように，う蝕柬の窩底
象牙質は象牙芽細胞突起や結晶で満たされており，健全 象牙質より残留モノマ一等の通過性がはるかに低いと考 えられている.今回実験に用いた被験歯はう蝕のない健 全新鮮抜去雪であり，厚さを一定にするため雨髄腔の天 蓋部分を削合し，また削合した茵髄腔側の象牙質のスミ ア一層を除去する目的でリン酸処理を行っている．レシ ンと象牙質との接着を臨床状態により近づけるため, 歯 を固定せずに実験に供した。このため 2 週間という実験 期間中に, 象牙細管中のコラーゲンの一部が変性, 溶解 した可能性がある.したがって，う蝕茵の䆚底象牙質よ り通過性が強いことが予想される。しかしながら，コン ポジットレジンの臨床症例は多種多様であり，今回の被 験㐘に近い症例も少なからずあることは十分予想でき， このような場合レシンの未反応物質が歯髄に達して障害 を起ししている可能性は十分あると考えてよく，レシン 修復に際しては，セメントによる裏装を行うことが良策 である。しかしながら，Tri-EDMA のような疎水性で 侵食性が強いモノマーの使用を避けることにより，臨床 操作上わずらわしいセメント裏装を行わずにすむ可能性 も示唆された。

\section{結 論}

コンポジットレシンンの未反応物質が象牙質を通過する ことによって歯髄を刺激する可能性を調べるために, 象 牙質を通過してくる未反応物質量を求めた.実験にはと 卜抜去大臼幽の象牙質を用い，裔底象牙質に種々の処理 を施してコンポジットレジンを充填した。 2 週間後象牙 質を通過し，䨑髄側へ達するコンポジットレジンの未反 応物質量を高速液体クロマトグラフィーにて分析した。 
さらにコンポジットレジンと窩底象牙質との接合状態を SEM で観察した。

コンポジットレジンの未反応物質は，象牙質を通過し 歯㵦側へ達することが確認され．この通過量は筒底象牙 質をリン酸エッチングしても，差は生じなかった。

化学重合型のボンディング材を使用した場合，ボンデ イング材を使用しなかった場合と比べてコンポジットレ ジンからの末反応物質の通過量に大きな差はなかった。 光化学重合型のボンディング材を使用した場合は未知物 質の通過は認められず，他のモノマーの通過量も減少し た、また，ボンディング材をコンポジットレジンと併用 せずに象牙質に適用した場合，その未反応物質は象牙質 を通過しなかった。

䈪壁を $\mathrm{FeCl}_{3}$ で処理すると Bis-GMA の通過が認め られなくなり，他の物質の通過量も減少した。

レシンと窩壁とのギャップは, 光化学重合型のボンデ イング材を使用した場合と简壁を $\mathrm{FeCl}_{3}$ で処理した場 合に減少あるいは消失した。
未反応物質の通過量はレジンと窩壁とのギャップの存 在, 窩洞に残されたアルコールなどの溶凨の存在, 象牙 細管の物理的な封鎖性に左右されることが示唆された。 すなわち, 光化学重合型のボンディング材を使用するて とによりギャップを少なくし，象牙細管を物理的に封鎖 させしかも接着の助けとなる $\mathrm{FeCl}_{3}$ のような象牙質処 理剤を使用するととにより，未反応物質の通過を減少さ せることが可能である。

謝辞

稿を終えるにあたり，本研究に慜切なで指導，で校閲 を賜わった恩師長野三代太教授に深甚なる謝意を捧げま す. またで校閲を賜わった菌科理工学講座小園凱夫教授 に深く謝意を表するとともに，終始熱心なで指導と数多 くのご教示をいただいた寺下正道助教授ならびに萧庸雄 助手に心から抢礼申しあげます．あわせて数多くので助 言ならびにで協力いただいた保存学第 1 講座各位に感謝 致します．また，分析上の御助言をいただいた福岡歯科 大学理工学講座宮崎光治助教授に深謝致します.

\section{引用 文 献}

1) Langeland, L.K., Guttuso, J., Jerome, D.R. and Langeland, K. : Histological and clinical comparison of Addent with silicate cements and coldcuring resin. J.A.D.A. 72:373384,1966 .

2）藤沢盛一郎：歯科用レジン充媜材料の溶血性および溶出性からみた in vitro の生物学的評価方法について。 日歯保誌 $21 ： 137-146 ， 1978$.

3) Stanley, H.R., Bowen, R.L. and Folio, J. : Compatibility of various materials with oral tissues. II : Pulp responses to composite ingredients. J. Dent. Res. $58: 1507-1517,1979$.

4 ) Cotton, W.R. : Comments on Dr. Stanley's presentation. J. Dent. Res. 58:1518-1521, 1979.

5 ) Eriksen, H.M. and Leidal, T.I. : Monkey pulpal response to composite resin restorations in cavities treated with various cleansing agents. Scand. J. Dent. Res. $87: 309-317,1979$.

6）猪越重久：新接着性レジンの歯髄刺激性について. 口病誌 $47: 410-426,1980$.

7) Brännström, M. : Communication between the oral cavity and the dental pulp associated with restorative treatment. Oper. Dent. 9:57-68, 1984.

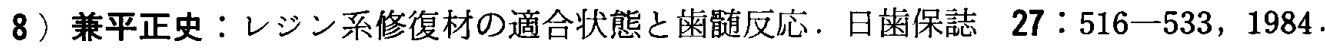

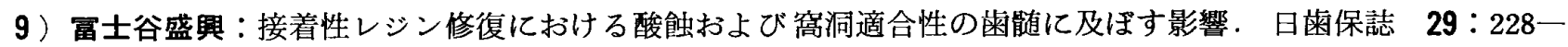
253,1986

10）総山孝雄・細田裕康・和久本貞雄・岩久生明：新保存修復術. ウ蝕治療革命の補遺整備. クインテッセンス 出版, 東京, $1985,85-93$.

11) Brännström, M. : Smear layer : Pathological and treatment considerations. Oper. Dent. Suppl. $3: 35-42,1984$.

12）藤沢盛一郎・增原英一：高速液体クロマトグラフィー（HPLC）による菌科用レジン充填材料の溶出物の分 析. 䨑科理工誌 $20: 121-131,1979$.

13）慶田安弘：董凩材のレジンモノマー遮断性に関する研究. 九州雪会誌 $36: 82-99,1982$. 
14) Fujii, K., Ginya, K., Arikawa, H., Kanie, T., Jyoshin, K., Inoue, K., Kuroki, K. and Uchiyama, C. : Composite restorative resins. Part 2 Physical and mechanical properties of UV and visible light activated composite resins. Dent. Mater. J. 5:252-259, 1986.

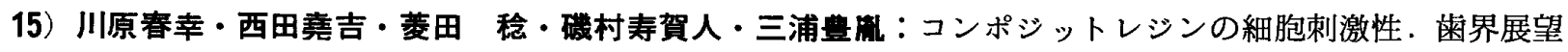
$47: 669-676,1976$.

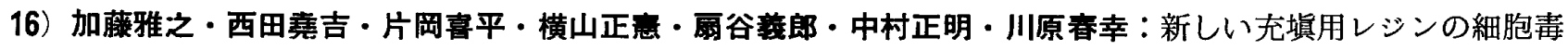
性に関する実験的研究 (in vivo). 㐘科理工誌 $2: 20-26,1979$.

17) Inoue, K., Arikawa, H., Fujii, K., Niihara, A., Fujita, R., Tsukada, G., Kuroki, K., Oka, T. and Uchiyama, C. : Composite restorative resins. Part 3 Cytotoxicity test to mouse fibroblasts in culture of $\mathrm{UV}$ and visible light-activated composite resins. Dent. Mater. J. $7: 55-61,1988$.

18) Brännström, M., Nordenvall, K.J. and Glantz, P.O. : The effect of EDTA containing surface active solutions on the morphology of prepared dentin : An in vivo study. J. Dent. Res. $59: 1127-1131,1980$.

19）清村正弥・阿部義人・中林宜雄 : 4-META-TBB 系レシンンの象牙質への接着. 日㐘保誌 28：277一284, 1985 .

20）千葉幹男・長谷川篤司・伊藤和雄・和久本貞雄：歯面処理法がレシンの接着性に与える影響について 第 2 報 エナメルおよび象牙質処理法についての検討. 日雨保誌 29:219-227，1986.

21）龩 㢈雄・河野直博・小川孝雄・寺下正道・長野三代太・小園凱夫：Dentin Bonding Agent の象牙質接 着性一ハイドロキシアパタイトおよびコラーゲンとの接着状態の観察. 日歯保誌 $30: 520$ - 526, 1987.

22）中林宜雄・神田和郷：2-メタクリロキシエチル p-メトキシフェニル リン酸を含むボンディング剂と象牙 質前処理剂の検討. 歯材器 $6: 396-402,1987$.

23）門磨義則・今井硢ニ：コラーゲンシート存在下における TBBO による MMA の重合に及ぼす第 2 鉄塩の 効果. 歯材器 $7: 817-823,1988$.

24) Doering, J. and Jensen, M.E. : A new photocuring dentin bonding material : Six month clinical results. J. Dent. Res. $64: 276,1985$.

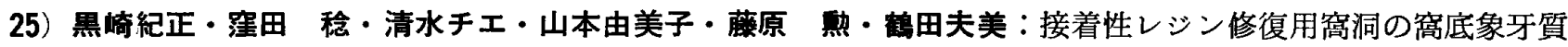
の特性. 日雬保誌 $30: 404-408,1987$. 